\title{
Determinants of Capital Structure of listed companies of textile and sugar sector during different economic periods
}

\author{
Noah Yasin \\ MBA Executive Scholar Foundation University Rawalpindi Campus
}

\begin{abstract}
This study examines that a large part of work on the capital structure remained focused on firm-level determinants across developed, emerging and developing economies. Subsequent work on capital structure emphasized on country level factors and few studies highlighted the significance of institutional differences (booth et al. ). However, the importance of sectors/industries with respect to firm's financial behavior remained untapped, particularly in developing countries like Pakistan. Keeping in view the characteristics of each sector/industry, they are subject to distinctive environment. For example, sectors have different nature in relation to growth opportunities, dynamics and concentration level. Hence, it warrants the need to investigate that how the nature of the sectors could affect the firm's capital structure decisions.
\end{abstract}

Keywords: Static Trade-off, packing order, capital structure, irrelevance theory, non-financial firms .

\section{General Overview :}

The total long term investments in a business firm is known as Capital Structure. The funds raised through ordinary and preference shares, bonds, debentures, term loans from financial institution, every earned revenue and capital surpluses are included. So now we are able to say that firm's capital structure is composed of its liabilities. The traditional theory of capital structure tells that firm's value goes on increasing to a definite level of Debt Capital, after that firms value inclined to stay stable and ultimately starts to decline.

When we see in the history, Modigliani and Miller (1958) gives theory of irrelevance according to which the company capital structure would not affect the firm's value. But this statement given by Modigliani and Miller on the basis of some Assumptions i.e. perfects markets should be available, no taxes applied, each and every information available to everybody. Their statement is not so much applicable in the real world but this statement provides grounds for the further studies or research.

Then later on, In their paper of 1963 , Modigliani and Miller broaden the basic proposition in their original work by giving allowance for the corporate profit tax in which interests payments are subtracted. They said that firm's value is the function of gearings and tax rate. Miller (1977) gives the extension to M \& M model to include the effects of personal taxes. In the light of M \& M model Miller says that this model overstates the benefits of corporate debt financing with the corporate taxes.

In 1976 Jensen and Meckling deliever the agency cost-based rationalization for the optimal capital structure Determination. Then in 1977 Myers also provide the same argument, which was provided by Jensen and Meckling as mentioned above.Ross in 1977 provide the other way to find the determination of firms capital structure on the bases of the presence of symmetric information on the both sides of the firms, insiders and outsiders. In 1984 Myers works finally results in the symmetric information theory of capital structure . Finally Myers suggests pecking order theory of the Capital Structure .

When there is a optimal target capital structure , the incremental tax shield benefit should be exactly offset by the incremental costs of financial distress. In the light of pecking order theory, firms tries to priority in their source of financing. This theory suggest to first go for R.E then for Debt and when there is no other option then go for equity as of last resort. Agency cost theory is a supposition that explains the relationships between the principal and agents in business. The major problem occurs between the principal and agents . one is when desires goal of principal and agents are in conflict. The other is when principal and agents have different attitudes towards risk because of this both takes different actions .

Signaling is the first effect on capital structure due to information with the proportion to the debt. In (1977) Ross mentioned that managers are the one who have the best knowledge relating to the income distribution of the firm. So when the firm take decision to go for debt this decision will send positive signal to the outside world about the firms financial condition. Because that firm will pay periodic installments and also has to pay interest amount which is fixed for that debt. So if the firm go for high debt proportion in their capital structure it will increase the confidence of the managers about the financial condition of the firm .

If we see in the history, a lot of work has been done on firm level and country level variables but the sector level variables are still less explore. So my study will also help to explore some sector level variables. Apart from firm level determinants of capital structure, few recent studies attempted to examine the affect of sectoral behavior on firm's capital structure. 


\section{Introduction :}

Companies face three fractions when to decide about their financing decisions. These fractions provide choice among three financing options i.e. debt, equity and retained profit. The construction of these fractions constitutes capital structure that is fertile area of research in corporate finance. In their attempts to maximize the value of firm, main target of the company is always been to select a suitable mix of sources of finance.

In this regard, cost of capital is considered as of paramount importance when to decide the financial structure of companies. For instance, debt is provide by the banks and other financial institution. The firms which employ the debt they have to face tradeoff between financial distress and tax shield benefits. Looking into the financial distress, companies may face possible bankruptcy. Bankruptcy costs are of two types, direct cost of bankruptcy and in direct cost. The former consists of the liquidation cost that is greater for the firms having small size but less for the firms having large size. Due to in-direct cost organizational policies changes such as, less budget for research and development, less budget for human resource capacity building that as a result could bring down fall in the sales revenue of the company.

Based on above strand, it is important to maintain the balance between the financial distress cost and tax shield benefits. On the other hand, if the firm is looking for financing through equity capital, they raise capital by the issuance of new shares. The asymmetric information in this regard plays crucial role in determining the value of these shares. It could cause underinvestment issues for the small size firms but large size firms have less asymmetrical information so the equity option could be good one for external financing for these large companies.

The primary decision in the capital structure is the decision either to go for debt or equity. Looking into different factors that could affect the firm's financial behavior/decisions, the firm seeks to develop the optimal capital structure which could be able to maximize the value of the firm. At the same time higher the expected rate of return that makes stock more valuable for the potential investors and other stakeholder, which in turn eventually increase stock price. So the optimal capital structure should be the one which maintain balance between the financial distress cost and advantage of tax shield to get final goal of maximizing the firm's value.

Since, path breaking study of 'theory of irrelevancy' by Modigliani and Miller , a large part of work on the capital structure remained focused on firm-level determinants across developed, emerging and developing economies. Subsequent work on capital structure emphasized on country level factors and few studies highlighted the significance of institutional differences (booth et al. ). However, the importance of sectors/industries with respect to firm's financial behavior remained untapped, particularly in developing countries like Pakistan. Keeping in view the characteristics of each sector/industry, they are subject to distinctive environment. For example, sectors have different nature in relation to growth opportunities, dynamics and concentration level. Hence, it warrants the need to investigate that how the nature of the sectors could affect the firm's capital structure decisions.

\section{Literature Review :}

First work is done by Modigliani and Miller (1958) according to them firms value is independent of the capital structure, this also known as M \& M theory of irrelevance.in the light of their study if both parties investor and the firm can employ at same interest rate then investor has the ability to neautralize any capital structure decision of firm. Although the above mentioned theory has its standing on some not practically physible assumptions but their study provide grounds for the futher studies on capital structure.

According to static trade off theory there are three factors by which firm adjustment toward the optimal gearing is influenced. Those factors are Taxes, agency costs and cost of financial distress.

Interest is the expense which is paid by the firm to the financial institution from where the firm had borrowed money. But this interest is not the expense for the firm for the large size firm which has large profits in their income statements. Because interest payments made by the firms are deductible from the tax payments of firm. So according to this theory firm will in try to go for more debt to increase their amount after taxes.

The chances of being default increases by taking debt beyond the optimal level of debt. If there is a situation that there is possibility that the firms may get defaulted on the repayment of their loan so in this case the control of the firm will shift from shareholders to the creditors by doing this creditors try to possess back their investment through bankruptcy process. Bankruptcy costs are of two types, direct cost of bankruptcy and in direct cost. The former consists of the liquidation cost that is greater for the firms having small size but less for the firms having large size. Due to in-direct cost organizational policies changes such as, less budget for research and development, less budget for human resource capacity building that as a result could bring down fall in the sales revenue of the company.

Agency cost theory is a supposition that explains the relationships between the principal and agents in business. Jenson and Slutz examined that problem of this theory can possibly solved or decreased if the debt proportion in the capital increases or the stake of the management is increased. 
Asymmetric information may have two different outcomes about capital structure. Insiders of firms have different point of view and outsides may have different view about firm' capital structure.

Signaling is the first effect on capital structure due to information with the proportion to the debt. In (1977) Ross mentioned that managers are the one who have the best knowledge relating to the income distribution of the firm. So when the firm take decision to go for debt this decision will send positive signal to the outside world about the firms financial condition. Because that firm will pay periodic installments and also has to pay interest amount which is fixed for that debt. So if the firm go for high debt proportion in their capital structure it will increase the confidence of the managers about the financial condition of the firm .

Those firms which have high proportion of debt can easily avail the option of debt due to their fixed assets which they can give to the banks as collateral. So those firms which have higher ratio of tangible assets , they can easily borrow debt easily at very reasonable rate. so this study will give the positive relationship between the gearings and Tangibility.

In accordance with the trade off theory, firms which have higher the ratio of fixed assets, those firms go for debt. But in accordance to the pecking order theory in the view of Harris and Raviv (1990), firms with less tangibility they have high asymmetric information, less option to go for equity so they go for debt. On the other side the larger firms can more effectively issue their shares, hence there should be reverse relationship between asset tangibility and leverage.

Apart from firm level determinants of capital structure, few recent studies attempted to examine the affect of sectoral behavior on firm's capital structure. According to previous studies, the measurement of industry level factors and data limitation was the major problem which was faced by these researcher in developing countries (Kayo and Kimura, 2011; Ramakrishnan, 2012). Keeping in view these certain limitations, no clear picture of sectoral affect on firm's financial behavior was obtained. Consistent with Kayo and Kimura (2011), in this purview to capture the more significant findings of sectoral effect on firms capital structure, this study further examining two industry level factors such as munificence and dynamics. In accordance with Beard and Dess (1984), munificence is the capacity of environment to maintain persistent growth. In this connection, firms operating under such environment have greater level of opportunities as compared to firms operating in less-munificence environment (Almazan and Molina, 2005). More recently, an inverse relationship between munificence and leverage was evident by Kayo and Kimura (2011), which confirmed the application of agency cost theory. The second industry level factor is environmental dynamism that explains the rate of variation in firm's external environment (Dess and Beard, 1984). Based on past literature, there are significant differences in terms of environmental factors impact on firms operating under different sectors (Jiao, Alon and Cui, 2011; Simerly and $\mathrm{Li}, 2000)$. In the above purview, to be the best of researcher's knowledge, upto now the sector's affect on the firm's financial behavior remained less-explored in developing economies, in particular Pakistan.

\subsection{Data Sources :}

\section{Methodology :}

This research is based on data retrieved from the World Bank Development Indicators and publications of the state bank of Pakistan "Balance Sheet Analysis of Joint stock companies which are listed on Karachi Stock Exchange for the period of 9 years from 2003-2011.

\subsection{The Sample :}

The study is based on non-financial firms (manufacturing firms) .the sample of the study includes textile and sugar sector firms. This sample is based on balanced data for which purpose all the firms for that complete data not available and the firms which are delisted by KSE are excluded from the sample. The final sample of study consists of 147 textile sector firms and 35 sugar sector firms which constitutes 1638 years observation

\subsection{Dependent and Independent Variables :}

Based on extensive past literature review and capital structure theories, the study in hand have taken five indepdent variables which include three firm-level and two sector level independent variable. The dependent variables are three types of debt that is, short term debt, long term and total debt. Following are the variables formulation and their hypothetical prediction.

There are different formulations for the measure of debt for example few studies have used market value of debt but large strand of studies used book value of debt as measure for leverage. Hence this study also used book value of debt for leverage measurement. 


\begin{tabular}{|c|c|c|}
\hline Variables & Formulation & Hypothetical Prediction \\
\hline \multicolumn{3}{|c|}{ Firm Level Variables } \\
\hline Tangibility & Ratio of fixed assets/total assets & Positive \\
\hline Size of firm & Natural log of sales & Negative \\
\hline NDTC & Annual depreciation/total assets & Positive \\
\hline Munificence & $\begin{array}{l}\text { 1. Regressing time against the sale } \\
\text { of an industry over the period of } \\
\text { study and } \\
\text { Taking the ratio of the regression } \\
\text { slope coefficient divided by mean } \\
\text { value of sale over the same } \\
\text { period }\end{array}$ & \\
\hline Dynamics & $\begin{array}{l}\text { Standard error of the munificence regression } \\
\text { slope co efficient divided by the mean value } \\
\text { of sales over the same period of study }\end{array}$ & \\
\hline \multicolumn{3}{|c|}{ Dependent variables } \\
\hline Short term debt & Short term debt/total assets & \\
\hline Long term debt & Long term debt/total assets & \\
\hline Total debt & Total debt/total assets & \\
\hline
\end{tabular}

\subsection{Theoretical Framework :}

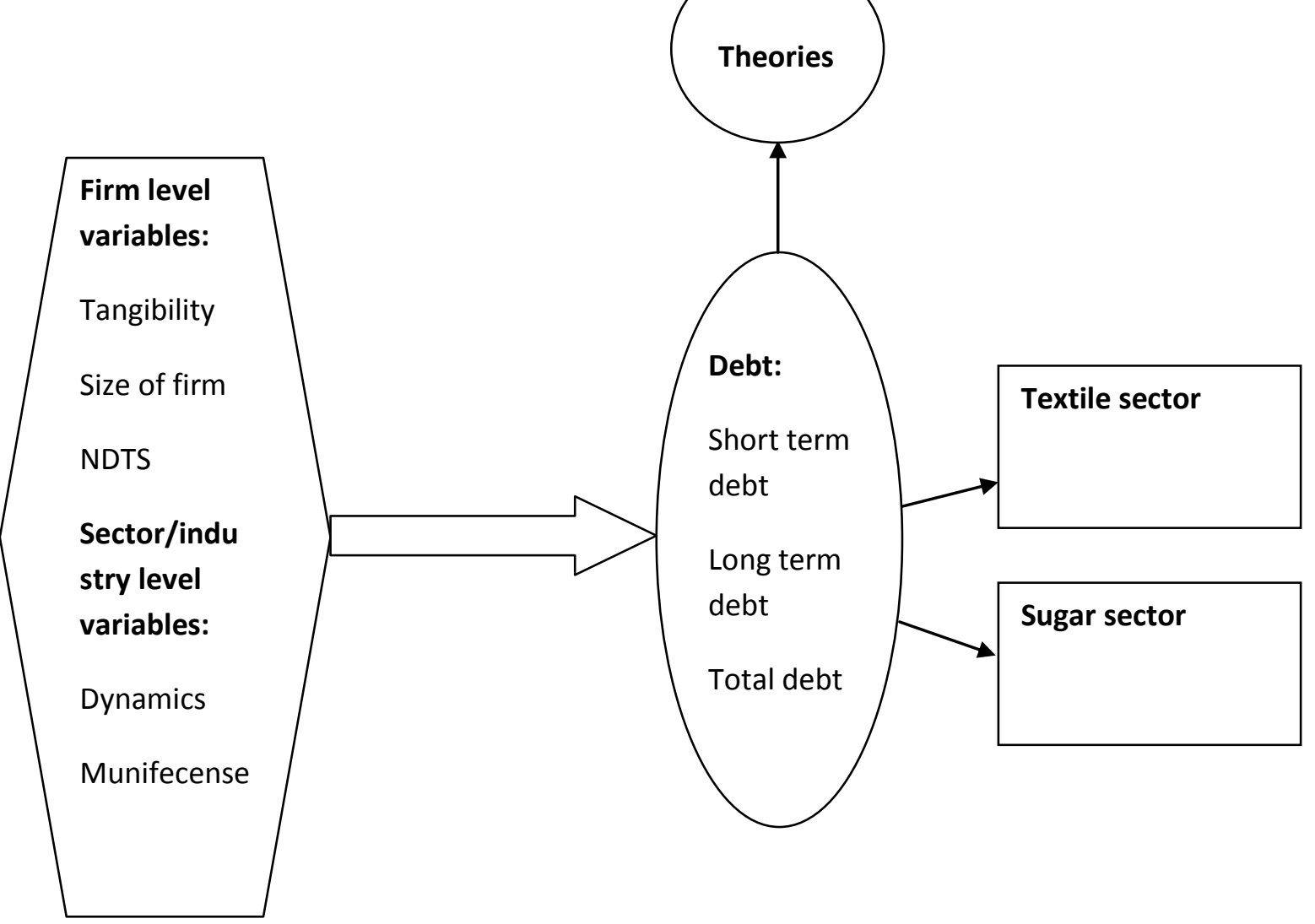

4.5 Model of the study :

As the nature of the study includes panel data which has the features of cross sectional and time series data. Therefore the study utilize pooled OLS Regression Analysis which is compatible for panel data.

$$
\mathrm{LG}_{\mathrm{it}}=\beta_{0}+\beta_{1}(\mathrm{SIZE})_{\mathrm{it}}+\beta_{2}(\mathrm{TANG})_{\mathrm{it}}+\beta_{3}(\mathrm{NDTS})_{\mathrm{it}}+\beta_{4}(\mathrm{MUNIF})_{\mathrm{it}}+\beta_{5}(\mathrm{DYNM})_{\mathrm{it}}+\varepsilon_{\mathrm{it}}
$$

$\begin{array}{ll}\mathrm{LG}_{\mathrm{it}}= & \text { Debt ratio of firm } \mathrm{i} \text { in time } \mathrm{t} \\ \beta_{\mathrm{O}}= & \text { The intercept of the equation } \\ \mathrm{SIZE}= & \text { Natural log of sale } \\ \text { TANG }= & \text { Tangibility of firm (Fixed Assets/Total Assets) } \\ \text { NDTS }= & \text { Non-Debt Tax Shield (Annual Depreciation/Total Assets) } \\ \text { MUNIF }= & \text { MUNIFICENCE }\end{array}$




\section{DYNM $=\quad$ DYNAMICS}

$\varepsilon_{\text {it }} \quad=\quad$ Error Term

\begin{tabular}{|c|c|c|c|c|c|c|}
\hline & Coefficient & Std. Error & t-ratio & p-value & & P-value/T-ratio \\
\hline Const & 0.524064 & 0.0883909 & 5.9289 & $<0.00001$ & **** & $0.001(5.92)^{* * *}$ \\
\hline Size & -0.180845 & 0.00909376 & -19.8867 & $<0.00001$ & **** & $-0.001(-19.88) * * *$ \\
\hline TANG & 0.68803 & 0.0398381 & 17.2707 & $<0.00001$ & $* * *$ & $0.001(17.27)^{* * *}$ \\
\hline NDTS & 0.000810177 & 0.000393796 & 2.0574 & 0.03976 & *** & $0.039(2.05)^{* *}$ \\
\hline MUNIF & 0.0115936 & 0.00600688 & 1.9301 & 0.05928 & $*$ & $0.059(1.93)^{*}$ \\
\hline DYNM & -0.0730479 & 0.0338902 & -2.1554 & 0.03597 & $* *$ & $-0.035(-2.15)^{* *}$ \\
\hline
\end{tabular}

\begin{tabular}{|l|l|l|l|l|}
\hline Mean dependent var & 0.763686 & & S.D. dependent var & 0.815564 \\
\hline Sum squared resid & 1258.972 & & S.E. of regression & 0.713215 \\
\hline R-squared & 0.237705 & & Adjusted R-squared & 0.235241 \\
\hline $\mathrm{F}(8,2475)$ & 96.47190 & & P-value(F) & $5.8 \mathrm{e}-140$ \\
\hline
\end{tabular}

\section{Results of the Analysis :}

Analyzing the results for the effects of independent variable on the dependent variable, we found that tangibility have positive correlation with the leverage and this relation is also statistically highly significant. This results also confirms our above mentioned hypothesis that there is positive relation between the asset tangibility and leverage. This result also support Meckling (1976) and Myers (1977) version of static trade off theory that gearing level higher with higher level of fixed assets.

Our second variable is size of the firm which is negatively correlated with the debt . this shows that if the size of the firm is high then they do not want to go for debt, they mostly desireable to use their retained earnings. This results also confirms the pecking order theory . because the large size firms have less asymmetric information Rajan and Zingales (1995) so these firms go for equity rather then to go for debt. The relationship of size of the firm and leverage is also statistically highly significant.

Non debt tax shield has positive correlation with the debt and the relationship of non debt tax shield and leverage is statistically significant.

Munificence is our sector level variable, munificence has positive correlation with the debt and statistically the relationship of Munificence and leverage is significant. Because the munificence means that environment is likely that where is persistent growth of business so in these environment firm are willing to take debt and financial companies also give them debt easily.

Dynamics is our second sectoral level variable, dynamics has negative correlation with the debt but it has statistically significant with each other. There is another reason of negative relationship between dynamics and debt because if the business is more risky then financial firms will also hesitate before giving them loan.

\section{Conclusion :}

In this paper we use pooled OLS Regression of panel data analysis to measure the financial behavior of companies of textile and sugar sector companies which are listed on Karachi stock exchange for the period of nine years. The result of this study shows that the relation of the tangibility and the debt is positive. Size and asset tangibility these variables are highly significant with the relationship to the debt or leverage .Firm's size showing negative relationship to the debt while the relation of NDTS and debt is positive. The above three independent variables are statistically significant behavior. In this study we have taken two sector level variable one is munificence which has positive relationship and other is dynamics which has negative relationship with the debt. But both variables munificence and dynamics are statistically significant.

As the previous studies done on firm level and country level variable but not so much work done on the sector level variable. so this study also provide the path for the further research on sector level variable studies.

\section{Future Recommendations :}

Researcher will also do itself further studies on sector wise analysis separately. This study has some time limitations and also the sector wise information is not easily available in the developing countries. 


\section{References :}

[1]. Balance Sheet Analysis of the Joint Stock Companies which are Listed on Karachi Stock Exchange (2011), The State Bank of Bank of Pakistan

[2]. Booth L, Maksmivoc V, Kunt and Aivazian V, work on Capital structures in developing countries , Journal of Finance , 56 , 87 530 (2001)

[3]. Hijazi T. and Tariq Y Determinants of the capital structure (research on the Pakistan cement industry) Lahore Journal of Economics , $11,64-90(2006)$

[4]. Myers, Majluf (1984), Corporate financing and investment decisions when the investor donot have the information but the firm have the information, Journal of Financial Economics , 13 ,188-721.

[5]. Harris and Raviv, Capital structure and the informational role of debt, Journal of Finance 45, $321-549$ (1990)

[6]. Ross "Determinants of the Financial Structure : The Incentive of the Signaling Approach." Bell Journal of Economics 8 , 43 - 60 (1977)

[7]. Rajan and Zingale " what we are able to know about the capital structure ? some facts from the international Data , Journal of Finance Vol 70, ppp 1435 - 1467 (1995) .

[8]. Modigliani and Miller " The Cost of Capital, Corporation of the Finance and Theory of Investment , The American Economic Review $45,151-597$ (1958). 